\title{
Ebola in Sierra Leone and DRC: lessons learnt
}

\author{
Sierra Leone experienced an Ebola outbreak from 2013 to 2016. The current outbreak in the \\ Democratic Republic of the Congo just hit the one year mark. ${ }^{1}$ Doctors lan Crozier and Eugene \\ Richardson worked in both places. They told Mara Kardas-Nelson about the differences and \\ similarities in the response in the two countries
}

\section{Mara Kardas-Nelson journalist}

Berkeley, USA

\begin{abstract}
Mara Kardas-Nelson: How does clinical care differ in Sierra Leone and DRC?
\end{abstract}

Ian Crozier: I got to Sierra Leone in August 2014, in the early days of the outbreak. We didn't have adequate numbers of clinicians, we lacked the necessary equipment needed for basic clinical or laboratory monitoring, we were using repurposed hospital spaces or rapidly constructed large tents that weren't equipped to care for severely ill patients, and we often didn't have effective operating protocols for care provision or for protection of healthcare workers.

In general, care at the bedside in DRC has advanced significantly. It's now routine to be able to closely monitor a patient's vital signs, and laboratory tests and results can be accessed daily. There are more clinicians staffing treatment units than in Sierra Leone, and these now often have key specialists like paediatrics, critical care, and obstetrics. And most care in North Kivu province, a major hotspot, is being delivered in innovative care spaces that allow a new level of care and interaction between the patient, clinical teams, and family members, such as the biosecure ALIMA CUBEs and innovatively designed treatment units constructed by Médecins Sans Frontières and Samaritan's Purse. ${ }^{2}$

In DRC it's possible to provide care that was not possible early in the outbreak in many parts of Sierra Leone. Newly developed supportive care protocols have been issued by WHO, and I have been very encouraged to see a more advanced level of supportive care increasingly "baked in" to the DNA of the response."

MKN: In West Africa many ill people stayed in the community, and many did not seek treatment at all. Do you see the same in DRC?

Eugene Richardson: In Sierra Leone patients didn't go to health facilities in part because there wasn't enough staff to treat them. That's not necessarily the case in DRC, which has four times the number of doctors per capita. But patients are still showing up to treatment units late and sometimes dying two or three days later. Or they're not coming at all.

A Lancet Infectious Disease paper said this was due to mistrust, claiming that only $25 \%$ of people in the DRC believe that Ebola is real. ${ }^{4}$ The paper suggests that "conspiracy theories" are driving the epidemic, but that discounts a very real history of colonial exploitation: the brutal rule of Leopold II of Belgium in the 19th century, the fact that the country's first democratically elected president was killed with the support of the US CIA in $1961 .^{5}$

There's a theme of people coming in a way that doesn't benefit people in the Congo. So of course they don't want to comply with outside forces. Rejecting intervention-it's almost like a habitual reaction now.

People have been dying from malaria, measles, and armed conflicts for years, and there's a sense that no one's come to help. And then all of a sudden they see people from abroad with SUVs and money. They feel like all of this is being foisted on them. They feel like we're the ones spreading Ebola.

MKN: One major problem in the West African outbreak was the lack of local clinicians. Does DRC have a similar problem?

IC: It's notable that most treatments units are staffed predominantly by Congolese clinicians rather than expatriate clinicians. That's very different from Sierra Leone, where most of the doctors were from outside West Africa.

Congolese clinicians are incredibly competent and have been resilient in a very difficult time, considering all of the attacks that have taken place amidst general insecurity in North Kivu. This has affected the ability to provide care. I was in Butembo and Katwa in March and April, when there were major attacks directly on treatment units. We had to move patients in the middle of the night, and then partners later left. ${ }^{6}$ All the advances we've seen-in staff, structures, supplies, and systems—-stall when they no longer have the sociopolitical traction they need. 
I find the Congolese clinicians' resilience remarkable. And though we didn't face this level of violence in West Africa, I also saw this resilience among healthcare workers from Sierra Leone, who dealt with serious material constraints that hindered their ability to provide care.

MKN: What are international organisations doing?

ER: Some NGOs have left DRC because of violence, so WHO has found itself in an implementing role, which is very different from its more technical role in the West Africa outbreak. WHO is taking on a lot of the logistics, like bringing in supplies, overseeing vaccination campaigns, and contact tracing. It's doing a good job, even though it hasn't had the funds it has needed throughout much of the response. The public health people from WHO AFRO [the African regional office] are doing incredibly good work, such as supporting in-community education about how Ebola spreads, an experimental vaccine, and treatment. ${ }^{7}$

In Sierra Leone the British and Sierra Leonean military and NGOs were running the show. In DRC the Ministry of Health was playing a leading role, although that's changed since the international emergency was declared. The government in Kinshasa has neglected the region historically and colluded in its plunder, so the idea of a militarised response here, as was done in Sierra Leone, is not possible, because people don't trust the military after years of armed conflict.

MKN: Experimental treatments have been offered in DRC through a randomised control trial. ${ }^{8}$ How is that working?

IC: Therapeutics have been widely available to patients who make it to a treatment centre, first through compassionate use, and now through the RCT clinical trial. Conversations around informed consent, which have included local and anthropological input, have been very carefully considered and are initiated by social workers and often include Ebola virus disease survivors. The RCT has been led by the DRC National Institute for Biomedical Research, in partnership with the US National Institutes of Health, WHO, and NGO partners.

From what I've seen there's been good community understanding and acceptance of this study. Indeed, almost every patient who's exiting a treatment unit as a survivor has received an Ebola virus specific therapeutic. That's a remarkable shift from Sierra Leone and the Western African outbreak in general, where less than $5 \%$ of all patients received an experimental therapeutic as part of a study or under compassionate use.
MKN: The DRC outbreak has continued for a year. Why isn't there an end in sight?

ER: I worry that a vertical, hypertechnical approach, with a focus on vaccinations and new drugs, is backfiring. It may be causing a lot of people to recoil. To access these new interventions people have to go through an ordeal of consent and paperwork. That does not normally accompany medical interventions, raising suspicion of ulterior motives.

I've been surprised to see how much refusal there is. In one village I visited, of a couple of hundred people, only eight people took the vaccine. I think this has to do with a habitual rejection that communities have as a reaction to depredation from Kinshasa and foreign entities over many decades.

Maybe we have to approach things differently. For example, we could consider paying people cash to get the vaccine, rather than assuming they'll trust an outside force. We also need to provide high quality care across the board, not just for Ebola but for malaria, obstetrics, surgical services-things that people need every day.

Ian Crozier is a clinician scientist contracted by Leidos Biomedical Research to the US National Institute of Allergy and Infectious Diseases. Eugene Richardson is an assistant professor of global health and social medicine at Harvard Medical School.

Competing interests: I have read and understood the BMJ policy on declaration of interests and have no relevant interests to declare.

Provenance and peer review: Commissioned; not externally peer reviewed.

1 Lok P, Stijntje D. Ebola: one year anniversary of epidemic in DRC is "unwanted milestone.". BMJ 2019;366:I500410.1136/bmj.15004.

2 Devi S. Frontline: a new treatment facility for Ebola virus disease. Lancet 2018;392:2428. 10.1016/S0140-6736(18)33118-0 30527407

3 World Health Organization. Optimized supportive care for Ebola virus disease. Jul 2019. https://www.who.int/publications-detail/optimized-supportive-care-for-ebola-virus-disease.

4 Vinck P, Pham PN, Bindu KK, Bedford J, Nilles EJ. Institutional trust and misinformation in the response to the 2018-19 Ebola outbreak in North Kivu, DR Congo: a population-based survey. Lancet Infect Dis 2019;19:529-36. 10.1016/S1473-3099(19)30063-5 30928435

5 Nzongola-Ntalaja G. Patrice Lumumba: the most important assassination of the 20th century. Guardian. Jan 2011. https://www.theguardian.com/global-development/povertymatters/2011/jan/17/patrice-lumumba-50th-anniversary-assassination.

6 Doctors Without Borders. DRC: MSF shuts down Ebola treatment center following violent attack. Feb 2019. https://www.doctorswithoutborders.org/what-we-do/news-stories/story/ drc-msf-shuts-down-ebola-treatment-center-following-violent-attack.

7 World Health Organization. Ebola virus disease: frequently asked questions. Oct 2018 https://www.who.int/ebola/drc-2018/faq-vaccine/en.

8 World Health Organization. Democratic Republic of the Congo begins first-ever multi-drug Ebola trial. Nov 2018. https://www.who.int/news-room/detail/26-11-2018-democraticrepublic-of-the-congo-begins-first-ever-multi-drug-ebola-trial.

Published by the BMJ Publishing Group Limited. For permission to use (where not already granted under a licence) please go to http://group.bmj.com/group/rights-licensing/ permissions 